CELSI Discussion Paper No. 25

MI GRATI ON I N I TALY | S

BACKING THE OLD AGE WELFARE

August 2014

DANIELA DEL BOCA

ALESSANDRA VENTURINI 


\title{
Migration in Italy is Backing the Old Age Welfare
}

\author{
CELSI Discussion Paper No. 25
}

August 2014

\section{Daniela Del Boca}

University of Turin, IZA, CHILD and Collegio Carlo Alberto

\section{Alessandra Venturini}

University of Turin, CHILD, IZA and MPC

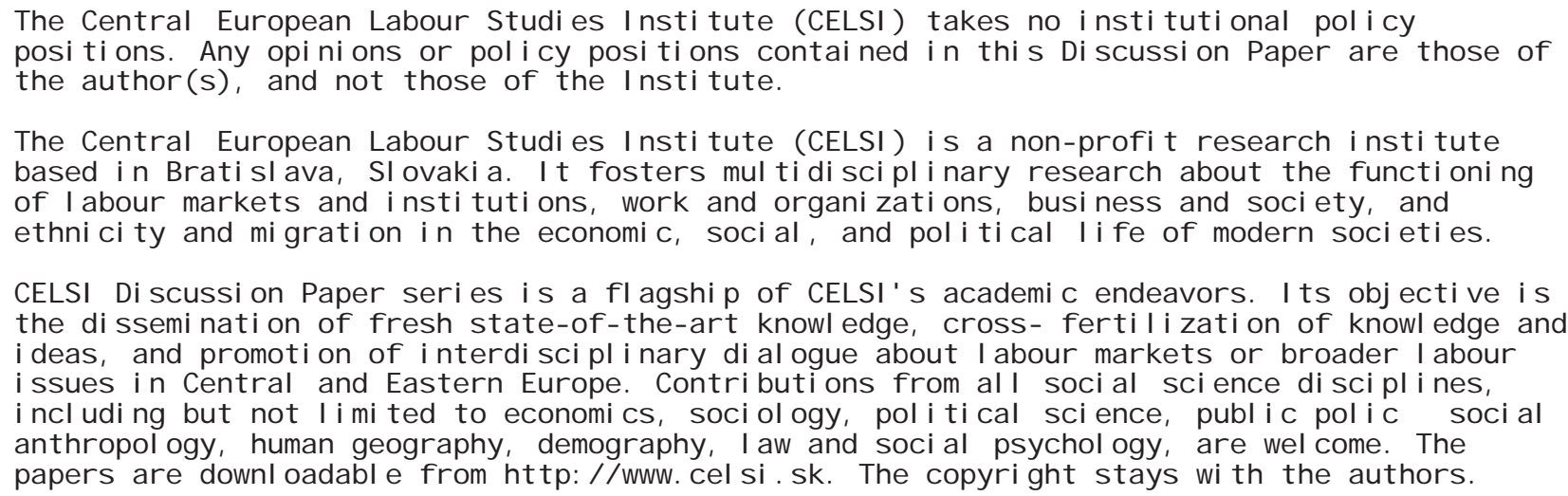

Central European Labour Studies Institute (CELSI)

$\begin{array}{ll}\text { Zvolenská } 29 & \text { Tel/Fax: +421-2-20735767 } \\ 821 \text { og Bratislava } & \text { E-mail: info@celsi.sk } \\ \text { Slovak Republic } & \text { Web: www. celsi.sk }\end{array}$


CELSI Discussion Paper No. 25

August 2014

\section{ABSTRACT}

\section{Migration in Italy is Backing the Old Age Welfare}

Our research analyzes the effect of changes in migration policies and the accession to the European Union of former countries of emigration, considering the crucial role played by migrants in an aging society. We focus on the demand of family-care workers by using the last five years of the Italian Labour Force survey dataset. Our results show that especially during the last years of recession, foreign labor (mostly female) has become fundamental in the family sector, favoring the participation of Italian skilled women in the labor market.

Keywords: migration, aging, women's work

JEL Classification: J6, J1 5, F66

\section{Corresponding Author:}

Daniela Del Boca

Department of Economics, University of Turin

Via Po 53, Italy

E-mail: dani.delboca@unito.it

\footnotetext{
* We would like to we would like to thank Daniela Piazzalunga and Laura Bartolini for their excellent assistance. Daniela Del Boca thanks Collegio Carlo Alberto and Alessandra Venturini the Migration Policy Center at the EUI and the Economic Department for technical and financial support. The authors thank also the anonymous referees as well as the editors of this volume for providing a number of suggestions that helped to improve the chapter significantly. We remain responsible for any mistakes still present.
} 


\section{Introduction}

Immigration in Italy became sizable at the end of the 1980s, with initial inflows from the Mediterranean countries, together with the Philippines, Latin America and some SubSaharan countries (including Senegal and Ghana). In the 1990s, following the dissolution of the socialist block and URSS, inflows increased at a higher pace, and the composition also changed with migrants coming from Albania and the other Eastern European countries. Poland was an early contributor, later replaced by Romania, Ukraine and Moldova.

Initially, most migrants were males working in agriculture and construction, as well as more limited numbers in the industrial sector. However, changes in the origin countries produced an increase in female migration as family members reunified, and produced a change in terms of first movers. In 2012, females comprised 53\% of the total foreign population, and this percentage is higher amongst Eastern European communities: e.g. Romania (64\%) and Ukraine (72\%). While this type of migration is driven by the economic downturn of the sending countries, the characteristics of supply are determined by labor specifics in the destination country. This demand is led by family services, namely care for aged persons, young children and housekeeping, which have a strong female preference.

This present research provides evidence concerning the effect of changes in migration policies and the accession to the European Union of former countries of emigration, while also highlighting the important role played by migrants in an aging society. Section 1 describes inflows onto the Italian labor market, while section 2 describes the changes in immigration inflows rendered by enlargement in 2007, including its effect on the likelihood of employment, by using the 2011 Italian Labour Force Survey dataset. Assimilation and down-skilling is analyzed in section 3 , and the role played by migrants in the labor market in section 4 . Section 5 explores further into this specificity, adopting a focus on the demand of family-care workers by using the last five years of the Italian Labour Force Survey. To conclude, section 6 analyzes recent employment trends for foreign nationals.

\section{Main characteristics of total migration, new accession countries and institutional setting}

In 2012 , the total foreign resident population was 4.859 million, or $8 \%$ of the native population ${ }^{2}$. The gender composition has changed over time: in 2004, men dominated and

\footnotetext{
${ }^{2}$ The data on residency permits only included the Romanian community until 2007. Thus, post 2007, we used the information available in the Population registers, which have annual data and which is released by Istat at http://dati.istat.it or the Labour force survey and the Labour force 
women represented only $46 \%$ of the total stock of migrants; in 2012 , they are on average $53 \%$ of the total stock. Foreign employment, and particularly foreign legal employment, has always been concentrated in northern Italy, (35\% in the north west and $26 \%$ in the north east), while central Italy covers $25 \%$ of total employment (mainly in Rome) and only $14 \%$ work in the south.

Male employment is found in industry (25\%), construction (25\%), commerce (20\%) and agriculture (5\%), while female employment is largely concentrated in the social and family services sector (on average 55\%, with higher peaks for some nationalities), with other women working in service activities (commerce 15\%) and only a minority (8\%) employed in the industrial sector.

\subsection{Characteristics of new accession countries}

The move from the first group and the most recent group of accession countries was driven by the labor demand in the household services sector. Prior to the fall of the Berlin Wall, Polish citizens were only able to reach Italy with a special visa to visit the Polish pope. They could subsequently remain undocumented, yet were perceived as temporary and tolerated because they were perceived as being in search of a visa to the US. Polish women came with a special tourist visa, which was renewed easily every three or six months, and they were attracted by job opportunities in the household services sector as caregivers. With the entrance of Poland into the EU, the attraction of such types of jobs declined, because the job opportunities increased at home and in the other EU labor markets that offered better job opportunities; for instance, the UK which did not apply for the restriction of migration ( 3 year transition period). At this point, the flow of Polish women declined but the demand for family services remained stable and even increased. Women from other Eastern European countries (Romania, Ukraine, Moldova, etc.) were subsequently sucked in by demand.

The flow from Romania initially concerned single men and women, with the rest of the family only coming afterwards. In 2002, the male-female ratio was 0.87 , while it is now 0.93 (see Chapter on Romania, THIS VOLUME). The inflow had two humps marked by legislative changes that eased entrance with visa liberalization in 2002 and accession in 2007. The Bulgarian community has always been less important, with a higher growth rate than the Polish community, and it remained at $10 \%$ of the Romanian (see Table $\mathrm{A}$ in the appendix). After 2007, Romanians were the most important foreign community, while Poles ranked $9^{\text {th }}$

survey, which provide individual data, available at http://www.istat.it/en/archive/36394 released by Istat every quarter with a sample survey of around 170,000 individuals. 
and Bulgarians $28^{\text {th }}$. Accordingly, we will only focus upon the behavior of the largest community, for which more and indeed better information is available.

Labor migration reflects the main reason to move to Italy for both men (66\%) and women (48\%), while family reunification only accounts for $23 \%$ of men and $43 \%$ of women, and has declined for both groups ${ }^{3}$.

\begin{tabular}{|c|c|c|c|c|c|c|c|c|c|c|c|c|}
\hline 2011 & & Total & Male & Female & & Total & Male & Female & & Total & Male & Female \\
\hline Activity rate & & 59 & 70 & 49 & Total & 69 & 83 & 57 & & 75 & 86 & 67 \\
\hline Empl.rate & Italians & 55 & 65 & 45 & Migrants & 61 & 75 & 49 & Romania & 67 & 79 & 58 \\
\hline Unempl.rate & & 7 & 7 & 8 & & 12 & 9 & 15 & & 11 & 8 & 14 \\
\hline
\end{tabular}

Source: Istat LFS, 2011, second quarter

Migrants have higher participation rates than natives (see Table 1), with the difference generally around $10 \%$, which explains the higher employment and unemployment rate both among male and female migrants. However, the Romanian community presents an even higher participation rate, particularly among females, as well as a very high employment rate, stressing that women are first movers and not only reunified family members. Indeed, this is a common trend among the Eastern European communities, driven by the high education level and participation rate diffused among women in the home country, as well as the economic transition faced by their economies, which has reduced job opportunities at home ${ }^{4}$.

Contrary to the native population, the prevailing contract type among the Romanian community is employee ( $91 \%$, native $73 \%$, total foreign national $87 \%)$. Self-employment is much less important (total $8 \%$, natives $26 \%$, total foreign nationals $12 \%$ ), which is maleoriented $(12 \%)$ and concentrated in construction.

The concentration of Romanian male migrants in construction $(42 \%)$ is much higher than the high concentration among the other migrants communities (27\%), and more than three times the native concentration (12.3\%). Moreover, they are also employed in the manufacturing sector, albeit less so than natives and other communities (22\%, $29.5 \%$ total migrants and $24 \%$ natives) (see Table $B$ in the appendix). Less important is employment in trade and transport (7.4\% and $8.2 \%$ respectively).

\footnotetext{
${ }^{3}$ See ISMU Report 2012, CARITAS 2011 and Pastore Villosio 2011.

${ }^{4}$ See Marchetti, Piazzalunga, Venturini 2012.
} 
Romanian female employment is even more concentrated, with $52.2 \%$ employed in social and personal services, $14 \%$ in hotel and restaurants and $10 \%$ in manufacturing. The female distribution for employment is far from the native distribution, yet is not so different from the average female migrant employment distribution: here, employment in the family sector can reach $72 \%$ and $80 \%$, as in the case of the Ukraine and the Philippine communities, but is largely disregarded by native Italians (7.8\%).

\subsection{Institutional setting of migration}

The importance of foreign workers in employment as caregivers is crucial for the Italian welfare system. Here, family has traditionally been the main source of basic assistance to the elderly, children and generally for all types of sicknesses not treated in hospitals. For this reason, migration policies reserved a specific legalization procedure for family caregiver workers, who are called badanti, the popular name used in the Veneto to define this type of service.

As a background to Italian migration policy, we should first recall that Italy became a country of immigration following the 1971 recession. With the introduction of restrictive immigration policies by Northern European countries, Italy became a second best destination for many migrants. However, the institutional setting and public opinion were not prepared for these kinds of changes. Accordingly, there were many subsequent legislative revisions and attempts to regularize - always for "the last time" - the spontaneous and thus nondocumented entrance of migrants.

If we consider residency permits, legal inflows were much larger in the legalization years than other years when visa policy and planned numbers were unable to control these flows and canalize migrants as they entered the country. Italy's very long frontier makes border patrol particularly difficult. However, spectacular boat arrivals only represent a small minority amongst non-documented inflows: most arrived by plane or land, or as tourists who subsequently work and overstay.

To cope with the inefficiencies in legal migration access, governments repeatedly legislated and, rather than reducing the non-documented presence in the country, called for additional spontaneous labor inflows, thus forcing the government to repeat legalization (as indicated by Figure 1). 
Figure 1. Laws on migration and amnesties, compared to flow of workers and family reunion members

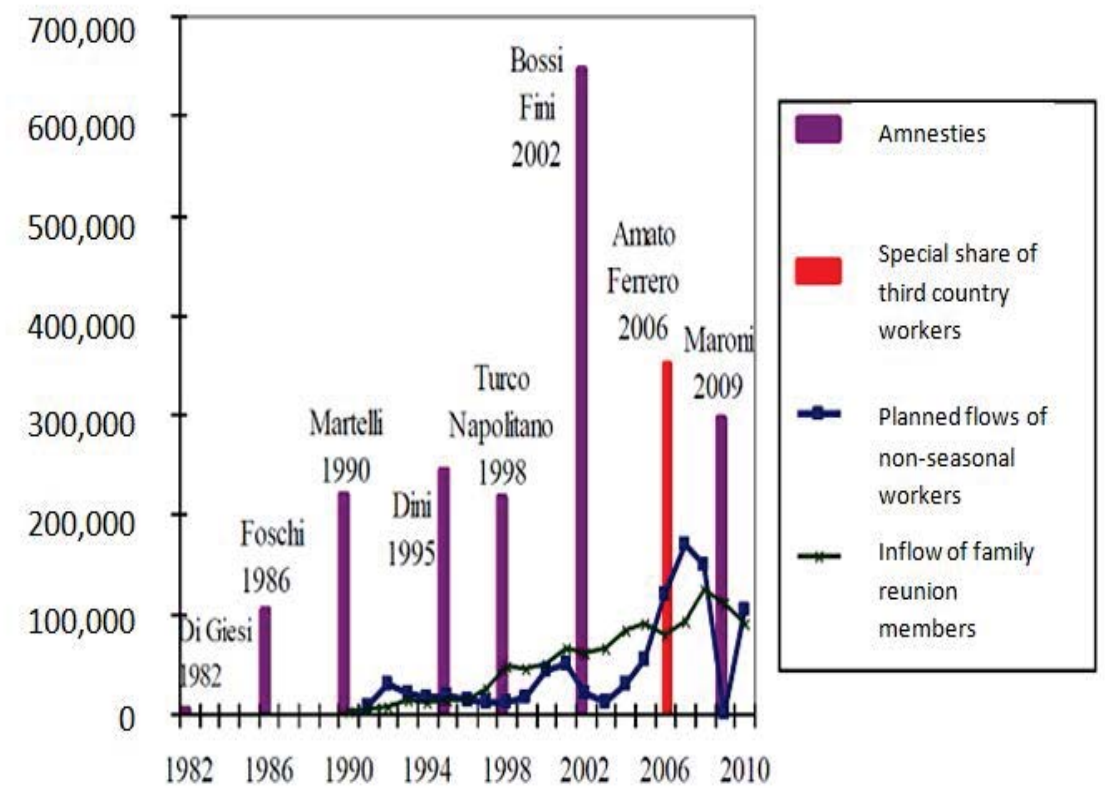

Source: Einaudi (2011).

In 2004, during the first enlargement, the majority of the EU countries, including Italy, requested a three-year transition period (with the exception of the UK, Ireland and Sweden). No significant change in immigration inflows and their flows occurred in Italy. Indeed, Italy did not even experience any relevant change at the end of the three-year transition period when free mobility came into being, because workers from the new accession countries were not drawn to the Italian labor market (see Figure 2). 
Figure 2. Stock of total and Romanian migrants (own calculation based on the population registers ISTAT)

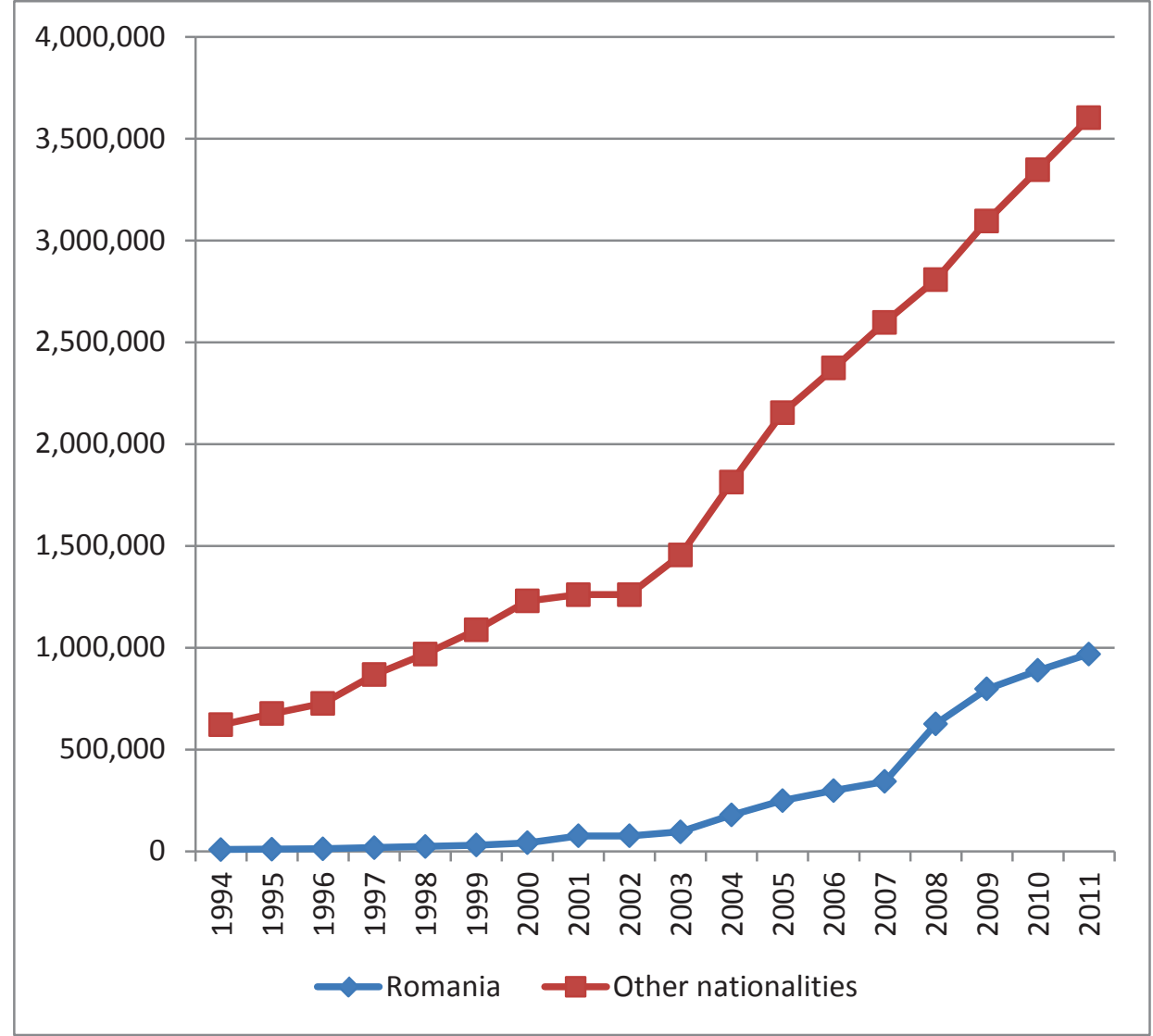

During the second enlargement in 2007 , Italy did not request a transition period. Overnight, all of the illegal Romanian migrants who had arrived with the expectation of enlargement became legal and thus the Romanian community doubled. Enlargement functioned as a larger and more specific legalization that produced limited changes in the composition of the flows, yet increased the size and role of the Romanian community. However, inflows from Romania had already increased in 2002, when the visa requirement to enter the country was eliminated. Indeed, the 2003 inflows already showed a higher pace of growth, which subsequently took off in 2007.

The institutional setting and large informal economy in the country - estimated at 30$40 \%$ of GNP, with large variation by sector and region - favored the non-documented labor entry and presence of non-documented labor migrants. Estimates for the share of informal employment or non-documented migrants vary between $8-15 \%$ of the total migrants stock ${ }^{5}$. This oscillation is a function of legalization policies that create an accumulation of non-

\footnotetext{
${ }^{5}$ Source ISMU 2012
} 
documented migrants, which declines after the end of the procedure and subsequently grows again later ${ }^{6}{ }^{6}$.

2. Has free mobility changed Romanian migration patterns? Has it increased the probability of Romanians finding a job?

In this section, we focus on the effects of policy changes on migration flows, their composition and expected duration, as well as the employability of migrants.

Considering the LFS (ISTAT), the characteristics of the inflows before and after the first legislative change in 2002 - when Italy eliminated the visa requirement for Romanian citizens and the 2007 enlargement - which eliminated the need for a residency permit -show a similar evolution, as Figure 3 reveals. In both cases, there was an increase in the young cohort and a reduction in those with secondary education, relative to those in other education groups.

\footnotetext{
${ }^{6}$ For more detailed analyses of irregular employment among Eastern European migrants in Italy, see Venturini, Marchetti and Piazzalunga 2012.
} 
Figure 3. Age and education before and after 2002 and 2007
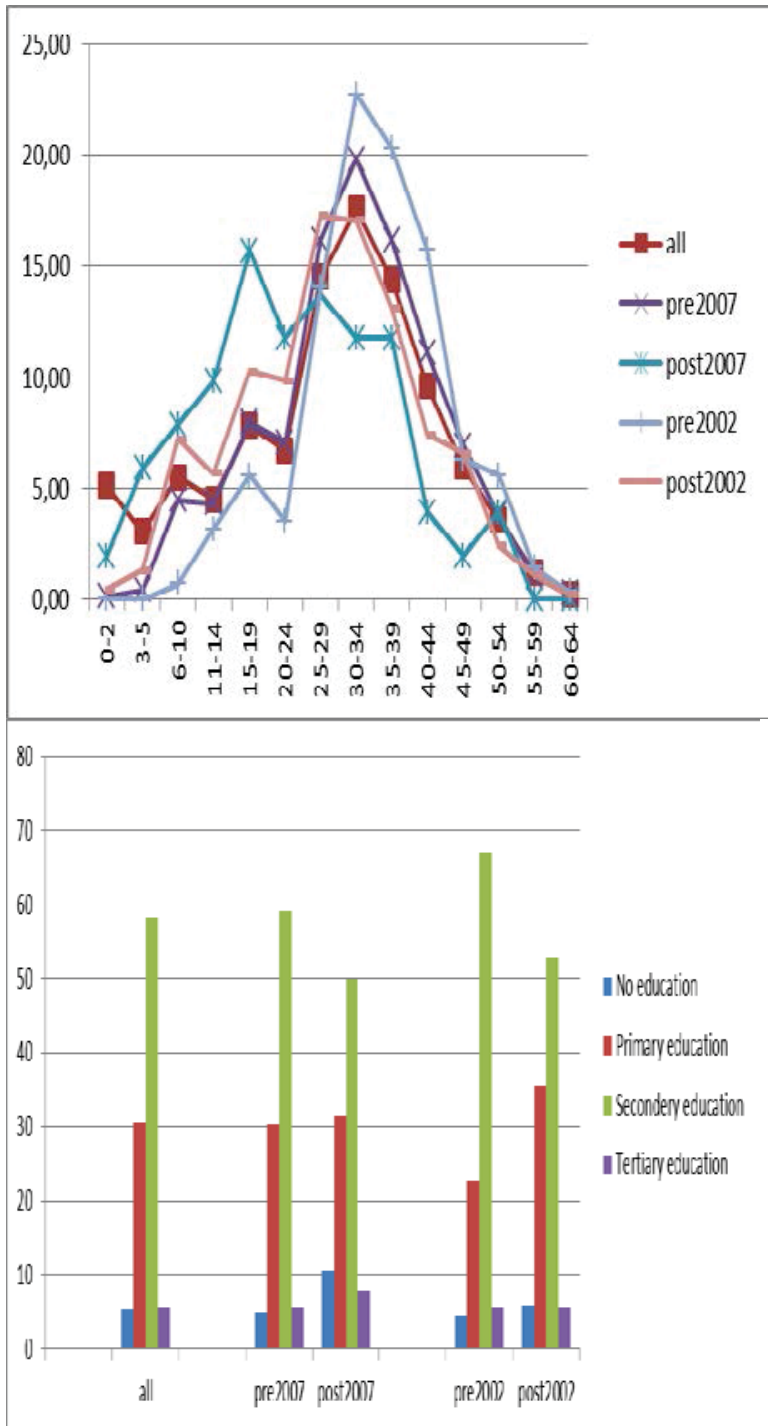

Source: own calculation on the LFS, ISTAT

Similar indications emerge from the survey conducted in 2009 inside the TEMPO research project by WIIW (Mara I., 2012) through ISMU in the three main Italian cities (Rome, Milan and Turin). This survey analyzes the changes between migrants who arrived before 2007 and those who came afterwards.

Those who arrived in the free mobility period are younger (concentrated in the 25-43 age bracket), with lower levels of education (secondary education decreases). However, the number of the highly educated also increased, while there were also more single migrants and fewer children. Men dominated the recent inflows because family reunification was led by women, while the share of persons living with a partner did not decline. 
The largest group in Italy is that which is less inclined to return to Romania and more likely to stay in Italy, with $30 \%$ of them changing their opinion after their arrival. For men, the drivers of change in migration plans were work (18\%), better standards of living (15\%), family reasons (13\%) and the negative economic situation in Romania (11\%). For women, the main driver was family $(28 \%)$, followed by work, earning and the "negative economic situation in Romania", which only accounted for $4 \%$. Uncertainty is much higher among the latecomers, and while men are ready to move to other destinations, $40 \%$ of females are ready to return to Romania. 37\% of the migrants who arrived after 2007 had previous experience of migration and probably planned a circular migration move that subsequently became more permanent owing to the limited jobs available at home.

Furthermore, the recent ISMU (2011) survey on migrant intentions, which is limited to Lombardy yet has a large sampling ${ }^{7}$, shows that $83.9 \%$ of Romanians answer the question concerning their "intention to move elsewhere within next 12 months" with a negative answer response. While this is a little below the average $(86.95 \%),{ }^{8}$ "yes to my country of origin", at $8.2 \%$, is far above the average of $5.3 \%$.

If free mobility has increased the possibility of return, the recession has reduced interest in going back home and has not increased back and forth mobility; however, the trend for more permanent migration has continued to be problematized by the increasing difficulties in finding jobs.

Has institutional change favored the employability of Romanian migrant workers? By using the most recent Labour Force Survey 2011, we have analyzed the probability of being employed or unemployed for those Romanian migrants who arrived before and after 2007. We wanted to understand whether the previous limitation to mobility had reduced job offers and, more generally, the employability of Romanians, who should be better off after the enlargement provided them with the freedom to move, which should favor better job matches.

As expected, what emerges from the results (Table $E$ in the appendix) is that higher education in northern Italy is positively related to the probability of employment. Meanwhile, being younger and female reduces the probability of employment. The dummies by ethnic group reported in column 1 of Table 2 indicate that the probability of employment for 26

\footnotetext{
${ }^{7}$ The interviews are conducted each year in Lombardy and 1,000 migrants are sampled.

${ }^{8}$ Only Ukrainians have a higher value at $8.5 \%$.
} 
European citizens ${ }^{9}$ is similar to their native counterparts. In the case of migrants from third countries, the probability of being employed is lower and the probability of being unemployed (column 2) is higher than for natives, as expected. Prior to the enlargement, the Romanian community behaved as third-country nationals and thus had a lower probability of finding a job; however, after enlargement, it behaved as other EU migrants and thus like native Italians. The variable indicates that the year since migration (YSM) is not statistically significant.

\footnotetext{
${ }^{99}$ All EU citizens minus Romanians.
} 
Table 2. Probability of being employed or unemployed in the 2011 LFS (own calculation)

\begin{tabular}{|c|c|c|c|c|c|}
\hline \multirow{4}{*}{ Specifications } & (1) & (2) & (3) & (4) & (5) \\
\hline & Empl & Unempl & Empl & Empl & Empl \\
\hline & TOT & TOT & FEMALE & MALE & Interactions \\
\hline & & & & & citizenship/YSM \\
\hline \multicolumn{6}{|l|}{ VARIABLES } \\
\hline \multirow[t]{2}{*}{ European 26} & -0.224 & 0.224 & -0.360 & -0.0229 & \\
\hline & $(0.192)$ & $(0.192)$ & $(0.241)$ & $(0.341)$ & \\
\hline \multirow[t]{2}{*}{ Romanian-pre07 } & $-0.351 * * *$ & $0.351 * * *$ & $-0.540 * * *$ & -0.105 & \\
\hline & $(0.130)$ & $(0.130)$ & $(0.177)$ & $(0.197)$ & \\
\hline \multirow[t]{2}{*}{ Romania-post07 } & -0.283 & 0.283 & $-0.541 * *$ & 0.0542 & \\
\hline & $(0.177)$ & $(0.177)$ & $(0.229)$ & $(0.289)$ & \\
\hline \multirow[t]{2}{*}{ Third-national mig } & $-0.594 * * *$ & $0.594 * * *$ & $-0.859 * * *$ & $-0.321 * *$ & \\
\hline & $(0.106)$ & $(0.106)$ & $(0.151)$ & $(0.151)$ & \\
\hline \multirow{2}{*}{$\begin{array}{l}\text { Year Since Migration } \\
\text { (YSM) }\end{array}$} & 0.00657 & -0.00657 & 0.0136 & -0.00261 & \\
\hline & $(0.00858)$ & $(0.00858)$ & $(0.0132)$ & $(0.0114)$ & \\
\hline \multirow[t]{2}{*}{ RomaniansYSM } & & & & & $-0.0405 * * *$ \\
\hline & & & & & $(0.0113)$ \\
\hline \multirow[t]{2}{*}{ Europeans26YSM } & & & & & -0.00988 \\
\hline & & & & & $(0.0145)$ \\
\hline \multirow[t]{2}{*}{ Third-Nationals YSM } & & & & & $-0.0323 * * *$ \\
\hline & & & & & $(0.00459)$ \\
\hline \multirow[t]{2}{*}{ Constant } & $1.924 * * *$ & $-1.924 * * *$ & $2.397 * * *$ & $2.071 * * *$ & $1.906 * * *$ \\
\hline & $(0.0863)$ & $(0.0863)$ & $(0.146)$ & $(0.102)$ & $(0.0860)$ \\
\hline Observations & 57,725 & 57,725 & 24,432 & 33,293 & 57,725 \\
\hline
\end{tabular}

The aggregate results seem to flag up the "accession agreement" having a positive effect, reducing the distance between the EU27 migrants and natives in terms of employment access. However, the analyses by gender (column 3 and 4) provide a different scenario. For both males and females, the pre-post agreement does not change the effect on the probability of finding a job, which remains negative for women and insignificant for men. Even before accession, men had the same probability of finding a job as native males, while females remained at a lower probability of sharing with third-country nationals. Further controls in column 5 confirm the results even for third-country nationals and Romanians. The seniority of migration expressed by the Year Since Migration variable cross-checked with the ethnic group is not positively related to the probability of employment: on the contrary, it discourages it. 
Seniority in the country of destination (YSM) does not capture the increase in human capital specific to the destination country, which is better captured by the wage variable. However, it is likely to capture an increase in the possibility of receiving unemployment benefits or working irregularly with a regular permit. This represents an opportunity for workers who do not have any career prospects and have previous habits of working in the informal labor market. Moreover, the longer that Romanian women stay in the destination country, the more likely they are to reunify their family and the more they want to leave the type of job for which they initially came.

In fact, for a large proportion, being residential caregivers (live-in) is difficult to combine with family life. Consequently, after the family arrives, they are likely to change to non-residential caregivers (live-out) or traditional housekeeping jobs. This change implies greater risk of unemployment than residential caregivers.

The evidence presented here suggests that even if Romanians prefer temporary migration, the limited options at home and weaknesses of the national pension fund (which recognizes yet rarely implements the portability of pension contribution) discourage their return. However, most Romanian migrants hope to return to Romania given the difficulties encountered in finding jobs in the destination country, and particularly finding jobs with career prospects. In the next section, we will discuss this issue in further detail.

\section{Migrants' assimilation or down-skilling?}

Under-skilling is not restricted to foreign workers; rather, it is also found among native workers. The foreign level of education replicates the education distribution of natives, with the highest concentration in secondary education and a lower concentration in tertiary education ${ }^{10}$. However, tertiary education is more common among natives (see Table $D$ in the appendix).

The occupation classification (ISCO see appendix table C) is more distorted, with both male and female migrants more likely to be found in low skill positions, while the share of workers regularly employed in low skill positions, both male and female, is increasing and reached $33 \%$ of total foreign employment in 2010.The employment distance is even higher for women, given that $45 \%$ of them are employed in unskilled household jobs.

\footnotetext{
${ }^{10}$ If the comparison is limited to the employed population, the share of native with Tertiary education grows to $18 \%$.
} 
There are many reasons explaining the amount of brain waste: the difficulties in the recognition of foreign education degrees; their different quality; and migrants' limited knowledge of the destination country's language. However, the most important reason relates to the lack of highly skilled job offers in the Italian labor market, which also spurs native workers to move abroad. Indeed, Italy has the largest brain mobility among EU countries, with $2.5 \%$ of the tertiary-educated emigrating.

Over-education persists. Using the 2005-2007 LFS dataset, Dell'Aringa and Pagani (2010) found that over-education stands at 41\% among natives and $90 \%$ among foreign nationals. However, what is worse is that while over-education decreases with experience for natives, experience among foreign nationals does not reduce over-education either at home or abroad $^{11}$.

In their analysis of wage and employment assimilation using a matched employers/employee administrative panel dataset, Venturini and Villosio (2008) found that migrants do not assimilate. In particular, Romanians who are employed in construction (male) and house services (female) are in jobs without career possibilities ${ }^{12}$. Acceturo and Infante (2010) analyzed the case of Lombardy, reporting that the return on education is positive, yet much lower than among natives (0.7-0.9\% versus $4.7-6-1 \%$ for natives). Strom, Venturini and Villosio (2012) show that there is a strong segmentation in the Italian labor market, and thus natives in "migrants jobs" (sectors with more than $16 \%$ for foreign employment) also have the same wage profile as foreign nationals and a very low probability of leaving these types of jobs, as well as permanent under-assimilation.

What emerges from these studies is that the Italian labor market mainly offers jobs without career prospects. Such jobs provide employment and income opportunities for foreign nationals, albeit without career advancement, and this relegates migrants from all countries into marginal positions.

EU accession has changed the composition of the Romanian community. However, the subsequent recession has reduced career opportunities for all workers and even more so for foreign workers.

\footnotetext{
${ }^{11}$ The probability of return is modeled as in Venturini and Villosio (2008) as a function of the income per capita

${ }^{12}$ Fullin and Reyneri (2010) model the assimilation as social class upgrading and the duration of stay in the country with the level of education as the factors favoring social upgrading for both woman and men.
} 
A self-evaluation of Romanian workers is reported in Mara's (2012) survey, where down-skilling is perceived as being more frequent for females, who are mainly employed in the family care sector. Romanian women seem to suffer $55 \%$ of down-skilling in terms of their previous position, while $10 \%$ have been upgraded and $30 \%$ hold the same type of occupation. Meanwhile, $65 \%$ of men have the same type of job as before, $10 \%$ have been upgraded and only $23 \%$ downgraded. As Figure 4 shows, the occupational shift of female Romanian migrants means that the higher the previous position, the more dramatic the down-skilling that follows. 


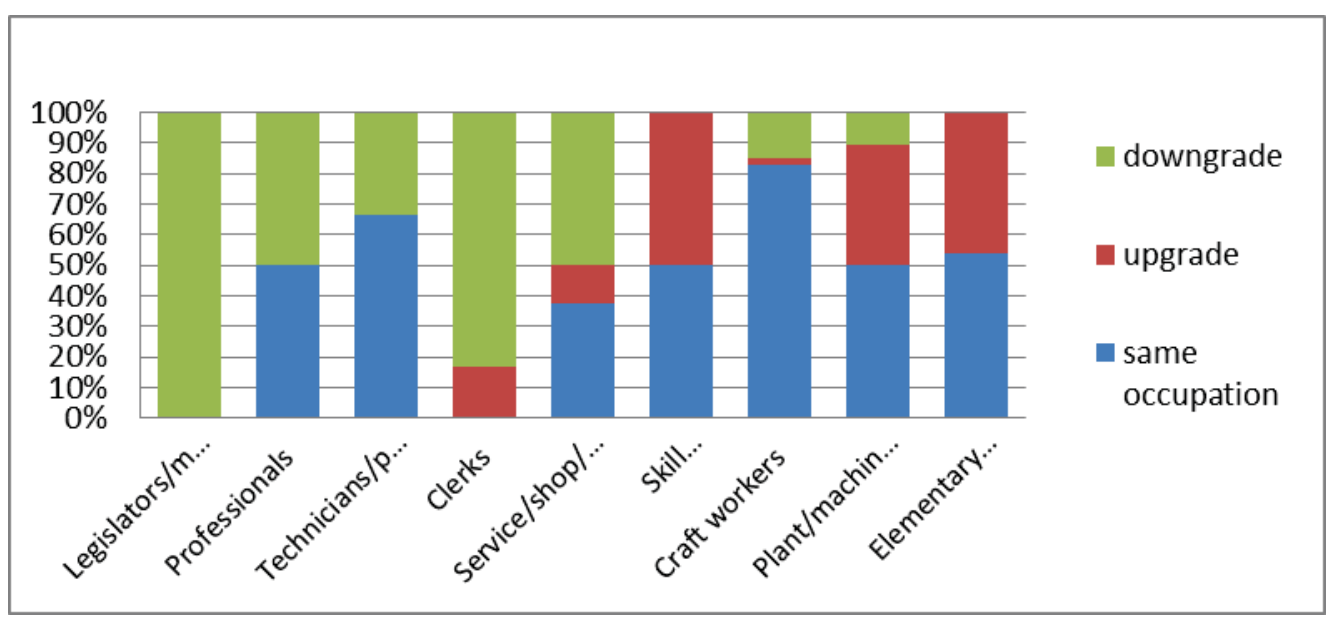

A more aggregate index of integration combining Economic Integration (EI), Social Integration (SI), Cultural Integration (CI) and Political Integration (PI) was undertaken by Cesareo and Blangiardo (2009) in a survey of 12,000 regular and irregular foreign nationals interviewed in all Italian regions. The index analyzes the different dimensions of integration and provides results for the different ethnic communities. The Romanian community is relatively balanced in all dimensions, while for instance the Chinese community is ranked $1^{\text {st }}$ in terms of economic integration yet amongst the last in other dimensions. The Economic Integration measure refers to housing, work and saving capacity, and the Romanian community, which holds a rank of 10 at aggregate level, is $15^{\text {th }}$ here, below the Albanian, Polish and Latin American communities. Their later arrival explains the lower economic integration, while their typical jobs - construction for men, household work for women - also plays a role. Furthermore, Romanians ranked $15^{\text {th }}$ for the Social Integration index, which measures friendly relations, participation in associations, and acceptance of the Italian life style, which again is a likely result of their typical jobs. In terms of the Cultural Dimension, which includes the knowledge and use of Italian, interest in Italian events, access to information, a sense of belonging to Italian society, migrants' self-perception of their well-being in Italy and their sharing of some integration ideals, the Romanian community ranks $10^{\text {th }}$. Finally, in respect of political integration, which refers to legal status, registration and opinions on the importance of citizenship, Romanians rank $9^{\text {th }}$. The survey generally points to a community that intends to settle and is thus interested in a legal stay and the life of the country; however, this community is still catching up economically and socially. The only other Community present in the survey among the accession countries is Poland, ranking $9^{\text {th }}$ with similar social and economic imbalances. 


\section{Effects on the domestic labor market}

Studies on immigrant workers in the Italian labor market date back many years. The first paper on the subject was provided by Gavosto, Venturini, Villosio (1999) ${ }^{13}$, who matched employer and employees data (WHIP) and used a cross sector and regional approach, yet did not find any significant effect on native wages. By contrast, Venturini and Villosio (2006) ${ }^{14}$ explored the effect of immigrants on the transition from employment into unemployment and from unemployment into employment among natives (divided into different skill and age groups), finding only a very small effect even among the most vulnerable categories, namely the young and female workers. Again using an employed-employees dataset for private firms (WHIP) and allowing for imperfect substitution between natives and migrants, Romiti (2011) did not find any impact on native wages and only a limited impact on highly skilled migrants. In order to understand the non-competitive role of migrants versus natives in greater depth, Bruecker, Facchin and Venturini (2011) analyzed the competition between foreign and internal migrants, showing that foreign migrants are not competitive with employed natives or those in search of a job in the destination area. By contrast, they displace internal mobility of labor aggravating the economic imbalances between regions.

More interesting is the new strand of research on the role played by migrants in the labor market, which follows on from the seminal paper of Cortes and Tessada (2011) on the effect of low-skilled migrant on the supply of highly skilled woman. Barone and Mocetti (2011) focus on the effect of female migrants on Italian female labor participation and weekly hours worked. The idea is that Italian woman still devote much time to household labor, given that services for young children are limited, as well as generally for the type of organization of their familial societies. Therefore, the presence of family help supports them in their labor force engagement. Barone and Mocetti find ${ }^{15}$ that while the labor force participation of native women is not significantly affected by the employment of foreign women, the hours worked (the intensive margin) by highly-skilled women are positively affected. The direct and indirect

\footnotetext{
${ }^{13}$ Gavosto, Andrea, Alessandra Venturini and Claudia Villosio.1999. “Do Immigrants Compete with Natives?" Labour, Vol.13, No. 3, pp. 603-622, which uses the Social Security data, matched employed employees dataset (WHIPS).

${ }^{14}$ They use the Bank of Italy employment survey, which has a retrospective question capturing the transition from previous jobs or unemployment into employment or vice versa.

${ }^{15}$ The authors used the LFS and estimated a reduced form equation of female labor supply with individual characteristics (age, education, children, marital status etc.), female unemployment, GDP per worker, population density, female immigrants specialized in household production lagged one year, regional fixed effect and interaction by region and year to capture regional business cycle. To instrument migrant working for the household they used previous allocation of male immigrants.
} 
effect on fertility does not play any role, while there is a positive correlation with full-time work for all education levels.

Taking into account the aging of society and lack of adequate social services, while remembering that the effort of taking care of the elderly is down to native women, Romiti and Rossi (2012) analyze the effect of total immigration on the female decision to retire early. They found that migrants employed in family services and, in general, all migrants reduce early retirement needs for highly-skilled native women by at least one year.

Empirical research shows that the balance between being a user of the welfare state, which is negative according to Pellizzari $(2011)^{16}$, is largely compensated by being a provider of services for the family, which favors female employment and a more equitable society.

\section{The welfare state and female migrants}

In this section, we explore both supply and demand for foreign workers in the household services sector in greater depth, including the important links with the characteristics of the Italian welfare state.

The Italian welfare state has been historically defined as a "pro-traditional" welfare state, given that the main care responsibility is for the family, while governments provide very meager support (Gautheir 1996, Ferrera 1996) ${ }^{17}$. Only 3.8\% of social expenditure is devoted to supporting the family, compared to the European average of $8.2 \%$ and higher values of $10 \%$ in France and North Europe ${ }^{18}$. Until the 1990s, care for the elderly in Italy was in fact provided by family members, especially women. According to the GALCA survey (Gender Analyses and Long Term Care Assistance), which compare structures and family responsibilities of elderly care in Italy and other countries ${ }^{19}$, more than $90 \%$ in both Italy and Denmark are assisted at home. While care responsibility in Denmark (as in other northern countries) is organized by the state, in Italy it is almost exclusively organized by family members. Until recently, Elderly care in Italy mainly rests on the shoulders of the family, with limited involvement of the private sector; consequently, informal networks continue to play an important role. Another important

\footnotetext{
${ }^{16}$ Contrary to previous research, Pellizzari shows that migrants use the welfare state more than natives if the regional level of services is also included.

${ }^{17}$ Ferrera (1996) classified Italy apart from other Southern European countries with family-based welfare state, based on the high level of fragmentation in the social protection system (generosity of some benefits, old age pensions and health care, as well as the low degree of intervention in the welfare sphere).

${ }^{18}$ IRES, 2009.

${ }^{19}$ Fondazione Brodolini (2004), GALCA Project, Final Report (Part 1).www.fondazionebrodolini.it/galca
} 
historical characteristic of the Italian family is the relatively high proportion of the elderly coresiding with their adult children. In fact, $30 \%$ of those over 65 lived with their adult children ${ }^{20}$, compared to an EU average of $15 \%$. Another important indicator of the historical strength of family ties is the residential proximity of children and parents, as well as the intensity of contacts between generations.

In the last few decades, demographic and economic changes have modified both the demand for elderly care and the availability of unpaid family-care work. Population ageing has increased the demand for elderly care, while the growth of women employment has reduced the supply of family members' unpaid care. While female immigration previously contributed to a profound change in the traditional model of family care, especially in respect of elderly care, immigrant women have started to complement/substitute the caring activities of women in the family and insufficient public services since the 1990s.

According to Bettio et al. (2006), around $5.6 \%$ of foreign nationals were employed in the household services sector between 1972 and 1982, while by 1991 they already represented $16.5 \%$ of the labor force employed in this sector. Their share has further increased drastically, current reflecting around 35\% of total employment. Families' readiness to resort to immigrants for elderly care can be explained by two factors, namely excess demand and low wages. Despite local authorities' increased efforts to intervene, particularly in the north, public provisions have remained vastly inadequate in quantitative terms and insufficiently flexible to ease the reconciliation of work and family life.

In order to explain the demand for female migrants as part of the private Italian welfare system, we analyze the determinants of regional demand in terms of a more restrictive one, "care givers", as well as a broader one, "domestic workers".

By "care givers", we refer mainly to women employed in family care sector for older people and young children, while the domestic workers include workers with housekeeping duties (proportion by region 2005-2009). ${ }^{21}$ Given the diffusion of informal contracts (Villosio, Bizzotto 2011), the second variable probably better captures the real dimension of the phenomenon. To construct the percentage of caregivers in the region, we follow Barone and Mocetti's approach. In the first case, we use the total number of women from Romania, Peru,

\footnotetext{
${ }^{20}$ Istat, Censimento generale della popolazione, 2001

${ }^{21}$ Given the data limitation we had to exclude Val d'Aosta, and to combine Abruzzi and Molise, thus we have only 18 regions.
} 
Ukraine, Ecuador, Poland and Bulgaria who are more specialized in the care sector over the resident population in the region. In the second case, we consider women from Romania, Peru, Ukraine, Ecuador, Poland, Bulgaria plus Morocco, Albania, Moldova, the Philippines and Sri Lanka who are specialized in house services ${ }^{22}$.

Our hypothesis is that the growth of female foreign nationals in the household-service sector relates to the availability of unemployed or inactive women, as well as the public services for the elderly provided at the regional level, both as public residences or medical and paramedical assistance at home. Therefore, we employ the number of people above $75^{23}$, the share of native women who are 25-64 years old, be they either unemployed or inactive ${ }^{24}$, the number of users out of 100 in public residential structure ${ }^{25}$ and the number of persons who receive residential assistance out of a 100 elderly residents ${ }^{26}$ as explanatory variables.

Our empirical analysis confirms our hypothesis: there is a positive relationship between the number of care givers/domestic workers and the proportion of the elderly, while there is a negative relationship with the number of native women who are unemployed or inactive. Assistance at home complements care and domestic foreign workers, while the number of older people in public residence is not significant. Female immigrants consequently have a very significant role in compensating the lack of public services, particularly for the elderly, complementing assistance at home and substituting family support.

\footnotetext{
${ }^{22}$ In order to select the countries to include we looked at the LFS and the number of foreign people working as skilled professionals in health and social services (cod.531), and as unskilled workers in household services (cod. 822).Source: dati.istat.it, population register, at $1^{\circ}$ January

${ }^{23}$ Source: Istat.it, population register

${ }^{24}$ Source: data .istat.it, labour force survey

${ }^{25}$ Source: Ministero del lavoro e delle politiche sociali, (novembre 2011) Second Report on self dependency inltaly, p.21. Data from Health Ministry (SIS-Sistema Informativo sanitario). This only includes people in residential structures publicly or privately recognized by the National Health Service. ${ }^{26}$ Source: Ministry of Labour and Social Policies, (novembre 2011) Secondo rapporto sulla non autosufficienza in Italia, p.21. data from ministero della salute (SIS-Sistema Informativo sanitario). Residential assistance includes both medical and non-medical assistance. In 2010 84\% of people assisted were 65 years or older.
} 
Table 3. Determinants of caregivers and domestic workers. Estimates from panel data 20052010 (standard errors in parentheses)

(1) (2)

VARIABLES

Care givers

Domestic

workers

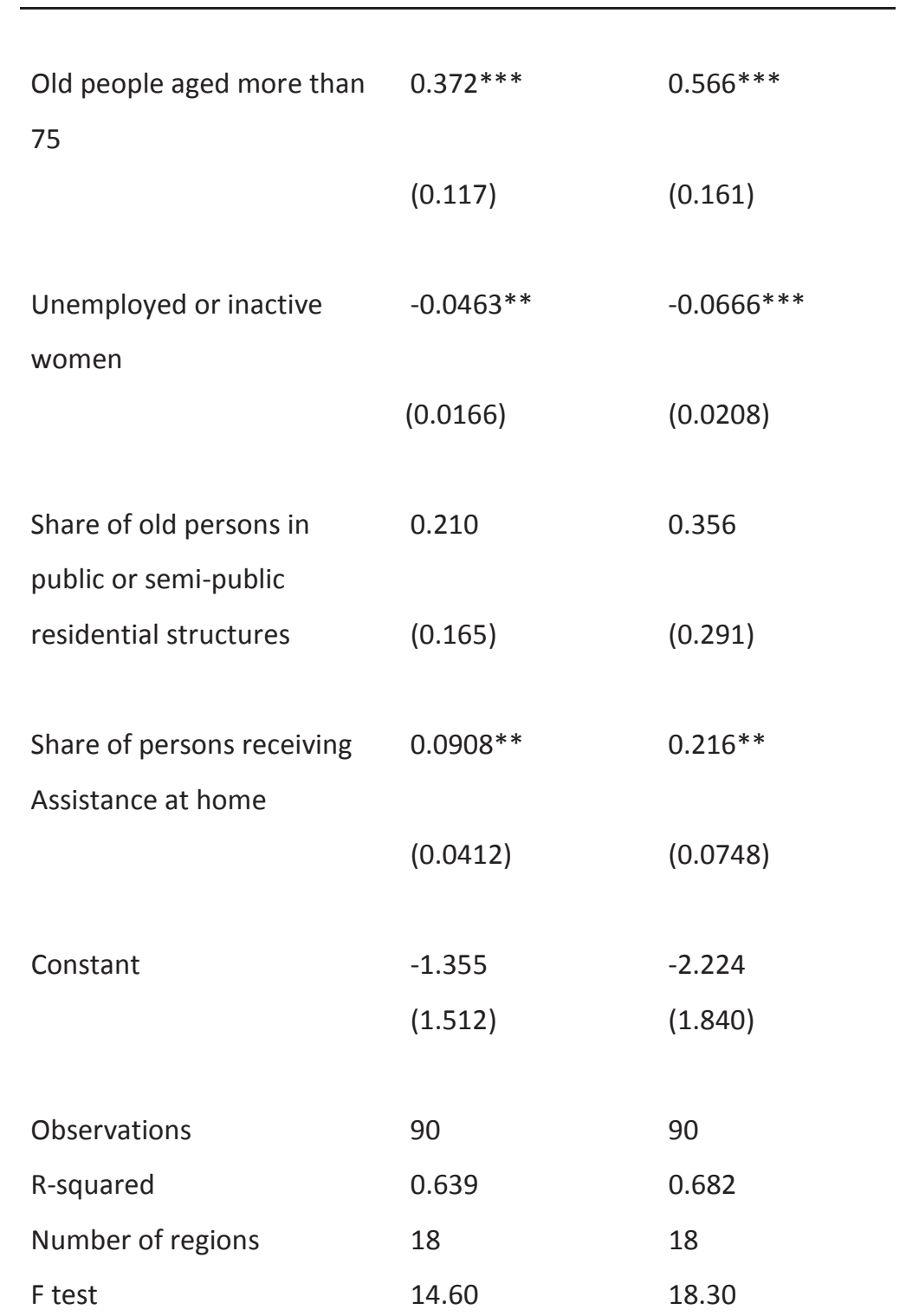

Care givers: share of foreign women from Romania, Peru, Ukraine, Ecuador and Poland in terms of the regional population

Domestic workers: share of foreign female workers from Romania, Peru,

Ukraine, Poland, Morocco, Albania, Moldova, Philippine, Sri Lank in terms of the total regional population. 
In Italy, immigrant female workers have allowed a new model of care for the elderly (Bettio et al. ii 2006.), a "new care mix" that has been able to overcome the structural deficiencies in public and family-care services. When compared with other European countries' systems, this model is proven less expensive and more flexible, thus able to overcome the structural deficiencies of the Italian public system and family care provisions. ${ }^{27}$

\section{Conclusion}

Migration in Italy responds to both the supply pressure of the sending countries and demand in the destination country. While it was initially limited to low-skilled jobs in the industrial, construction and agricultural sectors, it subsequently expanded to the family services sector, where elderly care is now monopolized by foreign women workers, with the availability of immigrant caregivers crowding out the alternative solutions that were in place. This employment sector is relatively heterogeneous given that it includes simple housekeeping work, as well as more complex care work among old or sick persons. Italy's ageing problem and the lack of sufficient and affordable private and public residential structures have created a demand for substitutes to allow Italian women to work outside the home. At present, a large share of welfare services are provided by foreign citizens in the private residences of needy persons or in public and private residential structures. Therefore, foreign labor not only serves for its contribution to the agriculture sector, in construction and industry, but is also fundamental in the family sector, favoring the participation of skilled Italian women in the labor market.

The recession has affected different sectors of the economy in different ways, with the large firms in the industrial sector dominated by native employment having been most affected. Therefore, natives initially suffered more from the economic downturn and their unemployment rate increased more than the corresponding rate of migrant workers, although this was higher to begin with. The construction sector, where migrants are largely employed, declined yet did not shrink abruptly as in Spain, because its growth was limited. Agriculture and small firms were affected, albeit only to a slight extent by declining demand. Unsurprisingly, the demand for old-age care remained stable, even if it was not constrained by labor supply as before. In general, foreign women were better off than foreign men; however,

\footnotetext{
${ }^{27}$ Hughes, G., Bettio, F., Reinicke, K. and Solinas, G. (2004) International Survey of Gender and Long Term Care of the Elderly. Synthesis Report. Roma: European Commission and Fondazione G. Brodolini.
} 
in 2011 the recession also limited the demand for family services given that some native women lost their jobs and became available for care services, while reduced budgets constrained family expenditure in all but the most vital areas. 


\section{References}

Acceturo A, Infante L (2010) Immigrant earnings in the Italian labour market. Giornale degli economisti e Annali di Economia 69(10):1-28

Barone G, Mocetti S (2010) With a little help from abroad: the effect of low-skilled immigration on the female labor supply. Temi di Discussione n. 766. Roma: Banca d'Italia.

Bettio F, Simonazzi A, Villa P (2006) Change in care regimes and female migration: the 'care drain' in the Mediterranean. Journal of European Social Policy 16(3)271-285

Bettio F, Villa P, Simonazzi A (2006) Welfare mediterraneo per la cura degli anziani e immigrazione. In: Simonazzi A (a cura di.) Questioni di genere, questioni di politica. Carocci, Roma

Bruecher H, Fachin S, Venturini A (2011) Do foreigners replace native immigrants? A panel cointegration analysis of internal migration in Italy. Economic Modelling 28(3):1078-1089

Castagnone E, Pastore F (2012) Migrant domestic work in Italy: Background overview. Fieri, Research Workshop for the EIF project "Promoting the integration of MDWs in Europe". ILO, Geneva, 17-18 January 2012

Cesareo V, Blangiardo GC (eds) (2001) Integration indexes. An empirical research on migration in Italy. ISMu, Milano

Cortes P, Tesada J (2010) Low skilled immigration and the labour supply of highly educated women. American Economic Journal: Applied Economics 3(3):88-123

Damuti F, Pinotti P (2010) Immigration and natives' labor market outcomes: evidence from Italy. Bank of Italy, Rome - mimeo

Del Boca D, Venturini A (2005) Italian migration. In: Zimmerman KF (ed) European Migration. What Do We Know?. Oxford UP, Oxford, pp 303-336

Dell'Aringa C, Pagani L (2011) Labour market assimilation and over-Education: the case of immigrant workers in Italy. Economia Politica (2):219-240

Einaudi L. (2011) Alcuni aspetti economici dell'immigrazione di lungo periodo in Italia. Second EMN National Conference, Rome, 9 November 2011.

Faini R, Strom S, Venturini A, Villosio C (2009) Are foreign migrants more assimilated than native ones?. IZA, Bonn, IZA Discussion Paper 4639

Fasani F. (2008) Undocumented migration. Counting the uncountable. Data and trends across Europe. Country report Italy. Clandestino. http://irregular-migration.net/typo3upload/groups/31/4. 
Ferrera M. (1996) The 'southern model' of welfare in social Europe. Journal of European Social Policy (6):17-37

Fondazione Brodolini (2004) GALCA project, Final Report (Part 1). www.fondazionebrodolini.it/galca

Fullin G, Reyneri E (2010) Low unemployment and bad jobs for new immigrants in Italy. International Migration 49(1):118-147

Gauthier AH (1996) The State and the Family: A Comparative Analysis of Family Policies in Industrialized Countries. Clarendon Press, Oxford

Gavosto A, Venturini A, Villosio C (1999) Do Immigrants Compete with Natives?. Labour 13(3): 603-622 Hughes G, Bettio F, Reinicke K, Solinas G (2004) International Survey of Gender and Long Term Care of the Elderly. Synthesis Report. European Commission and Fondazione G. Brodolini, Rome IRES (2009) II Lavoro domestico e di cura. Rome

ISMU (2012) XVII Report on Migrations. Milan

Marchetti S, Piazzalunga D, Venturini A (2012) Cost and benefits of labour mobility between the EU and the Eastern Partnership Countries, country study: Italy. IZA, Bonn, IZA Discussion Paper 7635

Marchetti S, Venturini A (2013) Mother and grandmother on the move. Labour mobility and the household strategies of Moldovan and Ukrainian migrant women in Italy. Forthcoming in: International Migration

Ministero del lavoro e delle politiche sociali (2011) Second Report on self dependency in Italy. Network Non Autosufficienza, 2011, L'assistenza agli anziani non autosufficienti in Italia. Maggioli editore, Rimini

Pasquinelli S, Rasmini G (2008) Badanti: la nuova generazione, Caratteristiche e tendenze del lavoro di cura. IRS.

Pellizzari M. (2011) The use of welfare by migrants in Italy. IZA, Bonn, IZA Discussion Paper 5613 Romiti A (2011) Immigrants-natives complementarities in production: evidence from Italy. CeRP, CeRP Working papers

Romiti A, Rossi M (2011) Should we retire earlier in order to look after our parents? The role of immigrants. CeRP, CeRP Working papers 
Venturini A, Villosio C (2006) Labour market effects of immigration into Italy: an rmpirical analysis. International Labour Review 145(1-2):91-118

Venturini A, Villosio C (2008) Labour-market assimilation of foreign workers in Italy. Oxford Review of Economic Policy 24(3):517-541

Villosio C, Bizzotto G (2011) Once there were wives and daughters, now there are badanti. Work in home elderly care in Italy is still an informal, unqualified and unrecognised occupation. Waling social 'partnership series. 


\section{Appendix}

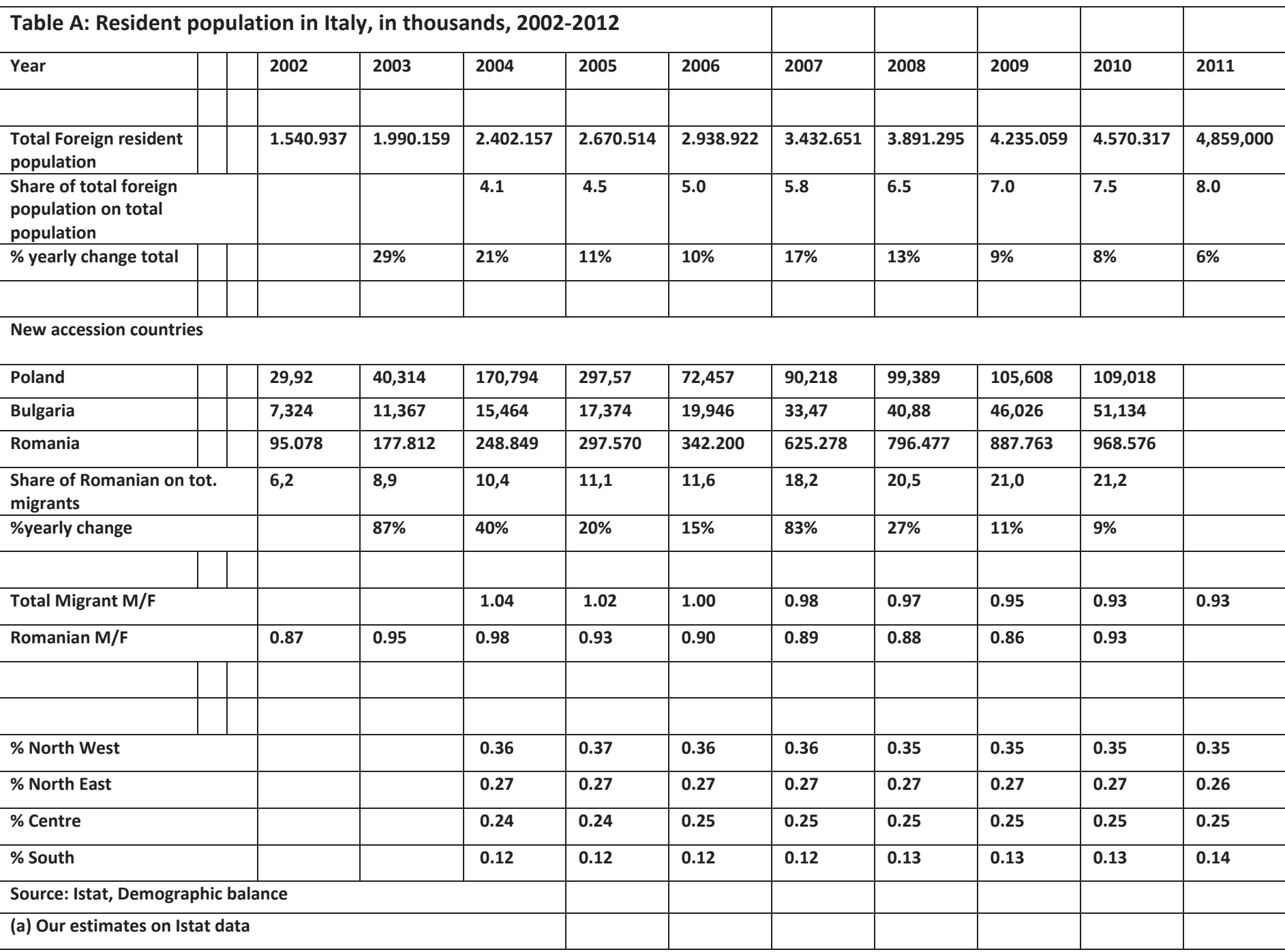

Table B Employment by sectors (NACE): male, female, natives, total foreigners and Romanians

\begin{tabular}{|c|c|c|c|c|c|c|c|c|c|c|c|}
\hline Origin & & Agricult. & Manufact. & Construct. & Trade & $\begin{array}{l}\text { Hotels } \\
\text { and } \\
\text { restaur. }\end{array}$ & Transport & $\begin{array}{l}\text { Inform. and } \\
\text { cmmunic. }\end{array}$ & $\begin{array}{l}\text { Business } \\
\text { activities }\end{array}$ & $\begin{array}{l}\text { Support } \\
\text { service } \\
\text { activities }\end{array}$ & $\begin{array}{l}\text { Public } \\
\text { services }\end{array}$ \\
\hline \multirow{3}{*}{ Romania } & female & 3,91 & 10,20 & 0,51 & 3,74 & 13,78 & 0,51 & 0,34 & 0,17 & 4,08 & 0,17 \\
\hline & male & 9,53 & 21,81 & 41,68 & 7,43 & 3,72 & 8,24 & 0,00 & 0,00 & 2,58 & 0,16 \\
\hline & total & 6,79 & 16,16 & 21,62 & 5,63 & 8,62 & 4,47 & 0,17 & 0,08 & 3,31 & 0,17 \\
\hline \multirow{3}{*}{$\begin{array}{l}\text { Total } \\
\text { immigrants }\end{array}$} & female & 2,82 & 9,38 & 0,50 & 5,74 & 13,02 & 0,77 & 0,36 & 0,32 & 8,42 & 0,27 \\
\hline & male & 7,62 & 29,46 & 26,81 & 10,99 & 6,55 & 6,27 & 0,45 & 0,14 & 4,69 & 0,07 \\
\hline & total & 5,55 & 20,81 & 15,48 & 8,73 & 9,34 & 3,90 & 0,41 & 0,22 & 6,30 & 0,16 \\
\hline \multirow{3}{*}{ Italian } & female & 3,27 & 12,75 & 1,50 & 14,50 & 6,84 & 2,22 & 1,63 & 2,86 & 11,67 & 6,34 \\
\hline & male & 5,32 & 24,62 & 12,25 & 14,57 & 4,31 & 5,91 & 2,33 & 2,73 & 8,97 & 7,88 \\
\hline & total & 4,47 & 19,69 & 7,79 & 14,54 & 5,36 & 4,38 & 2,04 & 2,78 & 10,09 & 7,24 \\
\hline
\end{tabular}


Table C Employment by Occupation (ISCO) male, female Natives, Total Migrants and Romanians

\begin{tabular}{|c|c|c|c|c|c|c|c|c|c|}
\hline & \multicolumn{3}{|c|}{ Highly skilled } & Skilled & \multicolumn{4}{|c|}{ Low skilled } & Unskilled \\
\hline & & $\begin{array}{l}\text { Legislators, } \\
\text { managers } \\
\text { and senior } \\
\text { officials }\end{array}$ & Professionals & $\begin{array}{l}\text { Technicians and } \\
\text { associate } \\
\text { professional }\end{array}$ & Clerks & $\begin{array}{l}\text { Service } \\
\text { and sale } \\
\text { workers }\end{array}$ & $\begin{array}{l}\text { Skilled } \\
\text { agricultural, } \\
\text { forestry and } \\
\text { fishery } \\
\text { workers, craft } \\
\text { and related } \\
\text { trades } \\
\text { workers } \\
\end{array}$ & $\begin{array}{l}\text { Plant and } \\
\text { machine } \\
\text { operators } \\
\text { and } \\
\text { assemblers }\end{array}$ & $\begin{array}{l}\text { Elementary } \\
\text { occupation }\end{array}$ \\
\hline \multirow[b]{3}{*}{ Romania } & female & 0,17 & 0,34 & 4,25 & 1,87 & 39,12 & 6,46 & 5,27 & 42,52 \\
\hline & men & 0,16 & 0,32 & 1,62 & 0,00 & 5,65 & 52,02 & 18,42 & 21,81 \\
\hline & total & 0,17 & 0,33 & 2,90 & 0,91 & 21,96 & 29,83 & 12,01 & 31,90 \\
\hline \multirow{3}{*}{$\begin{array}{l}\text { Total } \\
\text { immigrants }\end{array}$} & female & 0,64 & 2,46 & 4,92 & 2,37 & 38,11 & 6,79 & 4,78 & 39,94 \\
\hline & men & 0,90 & 1,65 & 2,55 & 1,14 & 9,34 & 42,63 & 17,71 & 24,09 \\
\hline & total & 0,78 & 2,00 & 3,57 & 1,67 & 21,73 & 27,19 & 12,14 & 30,91 \\
\hline \multirow[t]{3}{*}{ Italian } & female & 2,08 & 19,03 & 18,16 & 18,82 & 23,14 & 6,00 & 3,44 & 9,27 \\
\hline & men & 4,54 & 10,21 & 18,43 & 7,42 & 12,96 & 26,32 & 11,16 & 7,27 \\
\hline & total & 3,52 & 13,87 & 18,32 & 12,15 & 17,18 & 17,89 & 7,96 & 8,10 \\
\hline
\end{tabular}

Table D, Working age population $15-64$ by level of education (ISCED): male, female, Natives, Total foreigners and Romanians

$\begin{array}{llllll}\text { ISCED 0 } & \text { ISCED 1 } & \text { ISCED 2 } & \text { ISCED 3 } & \text { ISCED 5 } & \text { ISCED 6 2nd level of } \\ \begin{array}{l}\text { Pre- primary } \\ \text { education }\end{array} & \begin{array}{l}\text { Primary } \\ \text { education }\end{array} & \begin{array}{l}\text { Lower } \\ \text { secondary }\end{array} & \begin{array}{l}\text { Upper } \\ \text { secondary }\end{array} & \begin{array}{l}\text { Tertiary } \\ \text { education }\end{array} & \begin{array}{l}\text { tertiary education } \\ \text { (PhD) }\end{array} \\ & & \text { education } & & \end{array}$

\begin{tabular}{l|lllllll}
\hline \multirow{3}{*}{ Romania } & female & 2,71 & 2,85 & 25,30 & 60,87 & 8,26 & 0,00 \\
& male & 3,00 & 3,00 & 29,96 & 61,79 & 2,24 & 0,00 \\
& total & 2,84 & 2,92 & 27,45 & 61,30 & 5,49 & 0,00 \\
\hline \multirow{3}{*}{$\begin{array}{l}\text { Total } \\
\text { immigrants }\end{array}$} & female & 5,90 & 5,11 & 34,40 & 42,83 & 11,66 & 0,09 \\
& male & 5,96 & 6,07 & 40,63 & 40,56 & 6,59 & 0,19 \\
& total & 5,93 & 5,57 & 37,35 & 41,75 & 9,25 & 0,13 \\
\hline \multirow{3}{*}{ Italian } & female & 1,21 & 9,75 & 33,62 & 40,50 & 14,66 & 0,26 \\
& male & 0,79 & 6,68 & 39,33 & 41,11 & 11,78 & 0,31 \\
& total & 1,00 & 8,21 & 36,48 & 40,80 & 13,22 & 0,28 \\
\hline
\end{tabular}


Table E Probability of being employed or unemployed in the LFS 2011

\begin{tabular}{|c|c|c|c|c|c|}
\hline Specifications & $\begin{array}{l}(1) \\
\text { Empl } \\
\text { TOT }\end{array}$ & $\begin{array}{l}\text { (2) } \\
\text { Unempl } \\
\text { TOT }\end{array}$ & $\begin{array}{l}\text { (3) } \\
\text { Empl } \\
\text { FEMALE }\end{array}$ & $\begin{array}{l}(4) \\
\text { Empl } \\
\text { MALE }\end{array}$ & $\begin{array}{l}\text { (5) } \\
\text { Empl } \\
\text { Interactions } \\
\text { citizenship/YSM }\end{array}$ \\
\hline \multicolumn{6}{|l|}{ VARIABLES } \\
\hline EU26 & $\begin{array}{l}-0.224 \\
(0.192)\end{array}$ & $\begin{array}{l}0.224 \\
(0.192)\end{array}$ & $\begin{array}{l}-0.360 \\
(0.241)\end{array}$ & $\begin{array}{l}-0.0229 \\
(0.341)\end{array}$ & \\
\hline RO-pre07 & $\begin{array}{l}-0.351 * * * \\
(0.130)\end{array}$ & $\begin{array}{l}0.351 * * * \\
(0.130)\end{array}$ & $\begin{array}{l}-0.540 * * * \\
(0.177)\end{array}$ & $\begin{array}{l}-0.105 \\
(0.197)\end{array}$ & \\
\hline RO-post07 & $\begin{array}{l}-0.283 \\
(0.177)\end{array}$ & $\begin{array}{l}0.283 \\
(0.177)\end{array}$ & $\begin{array}{l}-0.541 * * \\
(0.229)\end{array}$ & $\begin{array}{l}0.0542 \\
(0.289)\end{array}$ & \\
\hline ThirdNat & $\begin{array}{l}-0.594 * * * \\
(0.106)\end{array}$ & $\begin{array}{l}0.594 * * * \\
(0.106)\end{array}$ & $\begin{array}{l}-0.859 * * * \\
(0.151)\end{array}$ & $\begin{array}{l}-0.321 * * \\
(0.151)\end{array}$ & \\
\hline Male & $\begin{array}{l}0.421 * * * \\
(0.0334)\end{array}$ & $\begin{array}{l}-0.421 * * * \\
(0.0334)\end{array}$ & & & $\begin{array}{l}0.427 * * * \\
(0.0333)\end{array}$ \\
\hline YSM & $\begin{array}{l}0.00657 \\
(0.00858)\end{array}$ & $\begin{array}{l}-0.00657 \\
(0.00858)\end{array}$ & $\begin{array}{l}0.0136 \\
(0.0132)\end{array}$ & $\begin{array}{l}-0.00261 \\
(0.0114)\end{array}$ & \\
\hline edu_low & $\begin{array}{l}0.370 * * * \\
(0.0673)\end{array}$ & $\begin{array}{l}-0.370 * * * \\
(0.0673)\end{array}$ & $\begin{array}{l}0.190^{*} \\
(0.114)\end{array}$ & $\begin{array}{l}0.473 * * * \\
(0.0839)\end{array}$ & $\begin{array}{l}0.402 * * * \\
(0.0669)\end{array}$ \\
\hline edu_medium & $\begin{array}{l}0.894 * * * \\
(0.0684)\end{array}$ & $\begin{array}{l}-0.894 * * * \\
(0.0684)\end{array}$ & $\begin{array}{l}0.843 * * * \\
(0.114)\end{array}$ & $\begin{array}{l}0.895 * * * \\
(0.0864)\end{array}$ & $\begin{array}{l}0.943 * * * \\
(0.0677)\end{array}$ \\
\hline edu_high & $\begin{array}{l}1.086 * * * \\
(0.0796)\end{array}$ & $\begin{array}{l}-1.086 * * * \\
(0.0796)\end{array}$ & $\begin{array}{l}0.989 * * * \\
(0.123)\end{array}$ & $\begin{array}{l}1.140 * * * \\
(0.112)\end{array}$ & $\begin{array}{l}1.134 * * * \\
(0.0791)\end{array}$ \\
\hline age14_24 & $\begin{array}{l}-2.519 * * * \\
(0.0745)\end{array}$ & $\begin{array}{l}2.519 * * * \\
(0.0745)\end{array}$ & $\begin{array}{l}-2.911 * * * \\
(0.125)\end{array}$ & $\begin{array}{l}-2.290 * * * \\
(0.0943)\end{array}$ & $\begin{array}{l}-2.565^{* * *} \\
(0.0742)\end{array}$ \\
\hline age25_34 & $\begin{array}{l}-1.447 * * * \\
(0.0703)\end{array}$ & $\begin{array}{l}1.447 * * * \\
(0.0703)\end{array}$ & $\begin{array}{l}-1.853 * * * \\
(0.118)\end{array}$ & $\begin{array}{l}-1.184 * * * \\
(0.0894)\end{array}$ & $\begin{array}{l}-1.488 * * * \\
(0.0699)\end{array}$ \\
\hline age35_44 & $\begin{array}{l}-0.742 * * * \\
(0.0703)\end{array}$ & $\begin{array}{l}0.742 * * * \\
(0.0703)\end{array}$ & $\begin{array}{l}-1.102 * * * \\
(0.118)\end{array}$ & $\begin{array}{l}-0.527 * * * \\
(0.0890)\end{array}$ & $\begin{array}{l}-0.762 * * * \\
(0.0702)\end{array}$ \\
\hline age45_54 & $\begin{array}{l}-0.384 * * * \\
(0.0720)\end{array}$ & $\begin{array}{l}0.384 * * * \\
(0.0720)\end{array}$ & $\begin{array}{l}-0.661 * * * \\
(0.121)\end{array}$ & $\begin{array}{l}-0.234 * * * \\
(0.0904)\end{array}$ & $\begin{array}{l}-0.395^{* * * *} \\
(0.0720)\end{array}$ \\
\hline NorthWest & $\begin{array}{l}1.027 * * * \\
(0.0523)\end{array}$ & $\begin{array}{l}-1.027 * * * \\
(0.0523)\end{array}$ & $\begin{array}{l}1.064 * * * \\
(0.0778)\end{array}$ & $\begin{array}{l}0.986 * * * \\
(0.0710)\end{array}$ & $\begin{array}{l}1.005 * * * \\
(0.0521)\end{array}$ \\
\hline NorthEst & $\begin{array}{l}1.358 * * * \\
(0.0598)\end{array}$ & $\begin{array}{l}-1.358 * * * \\
(0.0598)\end{array}$ & $\begin{array}{l}1.310 * * * \\
(0.0859)\end{array}$ & $\begin{array}{l}1.408 * * * \\
(0.0844)\end{array}$ & $\begin{array}{l}1.328 * * * \\
(0.0594)\end{array}$ \\
\hline Center & $\begin{array}{l}0.849 * * * \\
(0.0573)\end{array}$ & $\begin{array}{l}-0.849 * * * \\
(0.0573)\end{array}$ & $\begin{array}{l}0.783 * * * \\
(0.0832)\end{array}$ & $\begin{array}{l}0.907 * * * \\
(0.0801)\end{array}$ & $\begin{array}{l}0.830 * * * \\
(0.0572)\end{array}$ \\
\hline South & $\begin{array}{l}0.182 * * * \\
(0.0479)\end{array}$ & $\begin{array}{l}-0.182 * * * \\
(0.0479)\end{array}$ & $\begin{array}{l}0.195 * * * \\
(0.0738)\end{array}$ & $\begin{array}{l}0.170 * * * \\
(0.0631)\end{array}$ & $\begin{array}{l}0.176 * * * \\
(0.0479)\end{array}$ \\
\hline RoYSM & & & & & $\begin{array}{l}-0.0405^{* * *} \\
(0.0113)\end{array}$ \\
\hline Eu26YSM & & & & & $\begin{array}{l}-0.00988 \\
(0.0145)\end{array}$ \\
\hline ThirdNYSM & & & & & $\begin{array}{l}-0.0323 * * * \\
(0.00459)\end{array}$ \\
\hline Constant & $\begin{array}{l}1.924 * * * \\
(0.0863)\end{array}$ & $\begin{array}{l}-1.924 * * * \\
(0.0863)\end{array}$ & $\begin{array}{l}2.397 * * * \\
(0.146)\end{array}$ & $\begin{array}{l}2.071 * * * \\
(0.102)\end{array}$ & $\begin{array}{l}1.906 * * * \\
(0.0860)\end{array}$ \\
\hline Observations & 57,725 & 57,725 & 24,432 & 33,293 & 57,725 \\
\hline
\end{tabular}


www.celsi.sk

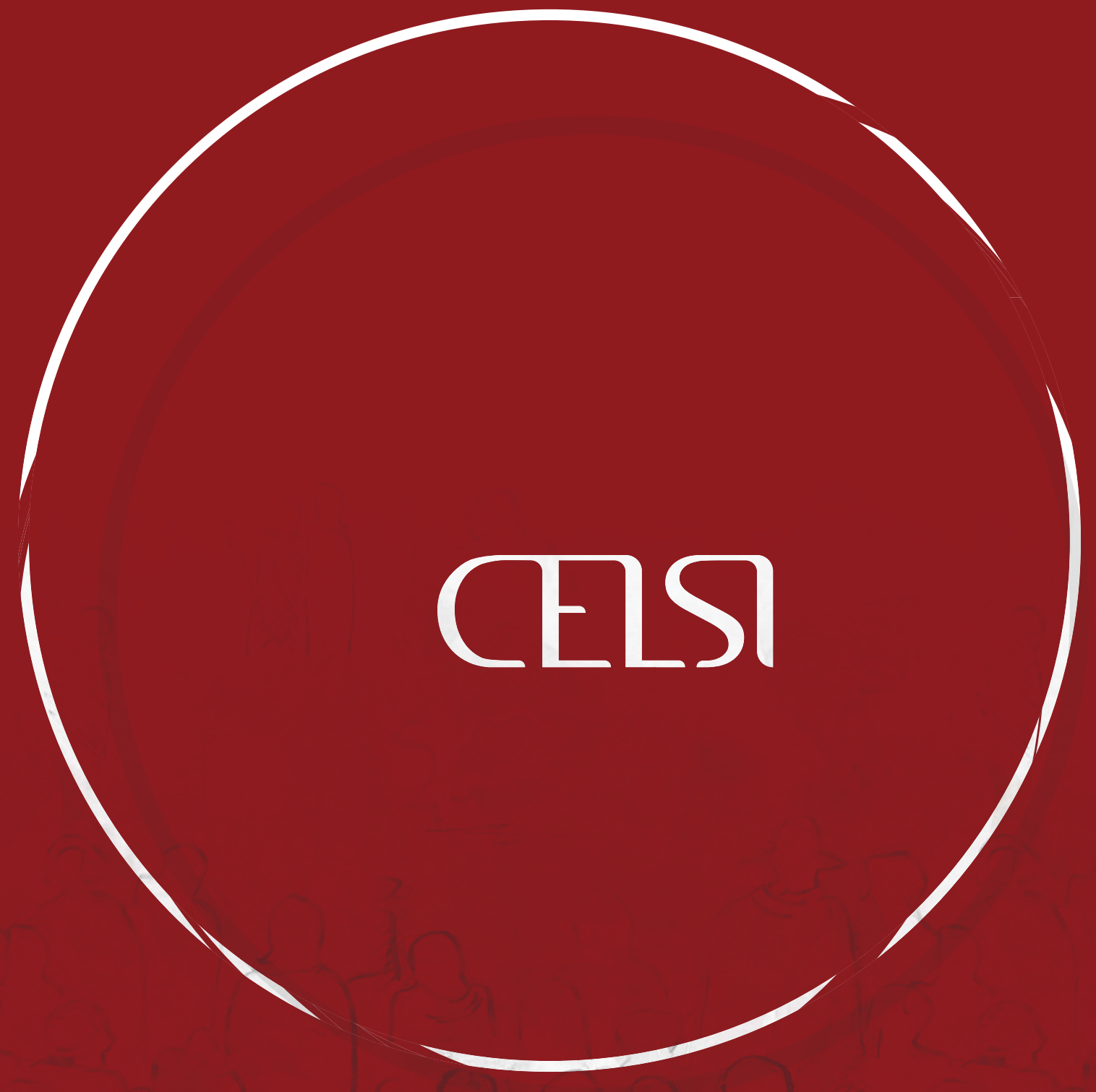

